\title{
EL JOVEN BORGES, BARROCO: UNA CALA DE FERVOR DE BUENOS AIRES
}

Respecto del primer libro de Jorge Luis Borges la crítica parece haber tomado una doble vertiente interpretativa: hay quienes, por una parte, buscan reducir Fervor de Buenos Aires (1923) a un común denominador y quienes, por otra, ven lo heterogéneo del volumen. El hecho de que no todos los poemas tengan como referencia inmediata la ciudad natal, Buenos Aires, así como la presencia de temas, formas y estilos varios, obliga a un análisis textual que permita ver los matices de un libro que, desde su propia concepción, tuvo fuentes de índole diversa: hay poemas hechos con versos recortados de poemas publicados previamente (la primera estrofa de "Campos atardecidos"), poemas publicados y reescritos para su inserción en Fervor (entre otros, "Ciudad", "Sala vacía” y "Llamarada"), poemas que se aglutinan para formar uno nuevo ("Sábados", "Campos atardecidos" y "Atardeceres"), poemas con versos entresacados de una prosa previa ("Las calles" y "Cercanías"), poemas cuyo manuscrito se remonta a la adolescencia del poeta ("Remordimiento por cualquier defunción" e "Inscripción en cualquier sepulcro") y, por último, poemas escritos ex profeso para este libro inaugural ("La Recoleta" o "El Jardín Botánico").

A menudo, la demostración de una tesis impera en los trabajos interpretativos y, en ese afán, se pierde el detalle o, bien, se ajusta el texto a una camisa de fuerza de la que siempre quedarán cintas sin anudar; por ejemplo, Rodolfo A. Borello aplica una fórmula para explicar Fervor: el criollismo que Borges defenderá abiertamente desde El tamaño de mi esperanza (1926) y luego en El idioma de los argentinos (1928) constituye el hilo conductor de Fervor. 
Borello avanza en su trabajo por dicotomías, entre las que destaca la del localismo vs. el cosmopolitismo: "El libro constaba de 38 poemas en los que no aparecía para nada el cosmopoli-

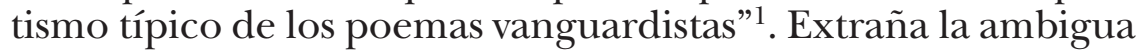
precisión con que Borello se expresa, porque nunca dice qué poemas representan el "cosmopolitismo típico" que, por cierto, Borges no parece haber privilegiado, hasta donde se sabe, en ninguno de sus manifiestos ultraístas. La dicotomía local/ cosmopolita que rige el trabajo de Borello lo induce a tildar de "costumbrista" este libro primerizo de Borges, y sus conclusiones tampoco escapan a la tesis general:

Cuatro aspectos entonces deben ser señalados en este libro: rechazo absoluto de las fórmulas ultraístas; adelanto -ya definitivo- de temas que se ampliarán y reiterarán en la obra futura; valor biográfico de ciertos poemas; la estructura y la reiteración anecdótica de varios poemas adelantan la forma y hasta los motivos que darán origen a cuentos más tarde famosos del mismo Borges ${ }^{2}$.

Otro crítico que, por ver el árbol, pierde la perspectiva del bosque es Rodrigo Zuleta. Él comenta que en Fervorse hallan los atisbos de una poética de la humildad; pero sus argumentaciones caen por su propio peso, pues utiliza una edición del poemario demasiado depurada, la de las Obras completas de 1989, reedición de la de 1974. Desde esta perspectiva, Zuleta observa atinadamente la poética de "la humildad" de los sucesivos Borges durante más de cincuenta años y, al menos, ocho intervenciones de Borges en Fervor. Según Zuleta, "El Sur" representa la primera definición de la "poética humilde" de Borges ${ }^{3}$. Sin

1 "El anacrónico Borges de Fervor de Buenos Aires (1923)", Río de La Plata, 1986, núms. 4/6, p. 113. El título del artículo sugiere la preferencia de Borges por un Buenos Aires en plena desaparición; pero no revela, por ejemplo, que al menos doce textos de la etapa ultraísta de Borges se hallan distribuidos en nueve poemas de Fervor, por señalar mínimamente cómo la generalización impide dar la justa dimensión al objeto de estudio. Borello también habla de 38 poemas, pero Fervor sólo se redujo a esa cantidad en 1943, porque en 1923 constaba de 46.

${ }^{2}$ Art. cit., pp. 118-119. Más contundente resulta la afirmación de Borello en el penúltimo párrafo de su estudio: "En 1923 nuestro escritor ha decidido agotar las posibilidades del criollismo, pero a la vez ha cortado toda relación íntima con el propio ruidoso comienzo vanguardista" (p. 119).

${ }^{3}$ Cf. "Fervor de Buenos Aires o la poética de la humildad", RF, 106 (1994), p. 261. Después de citar "El Sur", Zuleta señala que lo esencial en "el poema, 
embargo, se trata de un poema anacrónico agregado a Fervor cuarenta y seis años después de la primera edición, en 1969, lo mismo que "La rosa" y "Líneas que pude haber escrito y perdido hacia 1922", como Borges comenta a Antonio Carrizo, "para levantar un poco este volumen" .

Entre quienes han preferido ver la heterogeneidad de Fervor se encuentra Luis Martínez Cuitiño. A juicio de este autor, en el libro inaugural de Borges puede seguirse

un yo flâneur que prefiere para su deambular la hora del atardecer, un yo filosófico que reflexiona sobre los problemas de la metafísica, un yo histórico y mitificante que remonta el pasado y puebla el ámbito vacío con héroes y tiranos, el yo de un poeta que medita sobre su tarea, con un resto de ultraísmo evidente en el "enfilamiento de imágenes" o en la forma y abundancia de las metáforas ${ }^{5}$.

Esta interpretación menos generalizante ofrece una visión más fidedigna de Fervor, de sus múltiples planos estilísticos y temáticos, ya que se trata del análisis de "la pluralidad de egos del sujeto textual" ("Los «Borges» del Fervor", p. 68) y, por ello, de la heterogeneidad de la materia retórica y temática.

pues, no es lo extraordinario ni lo novedoso, por el contrario, lo habitual que parece haber estado siempre ahí y que ya ha sido repetido muchas veces. No se trata de buscar lo absolutamente inédito y presuntamente auténtico sino de ver cómo, infinitamente, se repiten muchas cosas”. El Borges maduro no podía ya caer, por su natural pudor, en las excentricidades cuya ausencia hace notar Zuleta. En un sentido semejante, Luis Izquierdo compara las versiones de "Sur" de la Obra poética de 1964 (con errores en la transcripción) y la de "El sur" de la edición de 1977 y concluye: "Es ya otro poema, y tal vez el mismo" ("La suscitación poética urbana en Jorge Luis Borges", en Homenaje al profesor Antonio Vilanova, ed. A. Sotelo Vázquez, coord. M.C. Carbonell, Universidad, Barcelona, 1989, pp. 278-279). Es otro poema con un título semejante: no pueden compararse. En 1943, Borges sí imprime cambios en "El sur"; luego, las ediciones de 1954, 1958, 1964 y 1966 reproducen esta versión, además de que cambia el título en 1964 a "Sur", hasta que es sustituido en la segunda edición de Fervor en 1969.

${ }^{4}$ Sobre "Líneas..." Borges expresa: "Ese poema no está en la primera edición. Yo quise hacer un poema a la manera antigua; es un arcaísmo deliberado. Se escribió cincuenta años después. Pero yo quise escribir un poema a la manera antigua, para levantar un poco este volumen. De modo que hice esa trampa. Y se lo confío a usted; ya que nadie nos oye podemos hablar" (Antonio Carrizo, Borges el memorioso, F.C.E., México, 1997, p. 161).

5 "Los «Borges» del Fervor", Letras, 1988, núms. 19/20, p. 52. 
El mismo Borges sugiere la convivencia de diversos planos en Fervor cuando informa a su amigo Jacobo Sureda, el 29 de mayo de 1922, que sigue "escribiendo el libro metafísico-líricogualicheante-confesional" 6 . La misiva, no obstante, sólo permite entrever una franja del espectro temático de Fervor, es decir, algunos poemas tenían un tinte más filosófico o amoroso o personal, si bien ayuda a fijar las fechas en que el primer libro de Borges se hallaba en gestación.

En su autobiografía, que data de 1971, Borges también recordaría de Fervor:

era esencialmente romántico, aunque estaba escrito con un estilo escueto y abundaba en metáforas lacónicas. Celebraba los atardeceres, los sitios solitarios, los rincones desconocidos; se aventuraba hasta la metafísica de Berkeley y hasta la historia familiar; registraba primeros amores... Me temo que el libro fuera un budín de pasas: había demasiadas cosas alli ${ }^{7}$.

Además de los temas referidos, agrega el de la celebración de los atardeceres, los espacios preferidos en sus caminatas y el de la historia familiar. También en una entrevista con Sorrentino, Borges dirá que "en cuanto a los temas, creo no haber cambiado... los temas de la perplejidad filosófica, la idea del tiempo, la idea del carácter onírico del mundo ya están en Fervor de Buenos Aires y están también en Elogio de la sombra, por ejemplo" ". Borges está siempre dispuesto a aceptar la diversidad temática en Fervor, como se observa en sus declaraciones; al mismo tiempo hace más énfasis en unos temas que en otros, según la intención del momento.

La lectura textual de Fervor permite sugerir una serie de temas que, desde mi perspectiva, se corresponden con estilos específicos. En este artículo me enfocaré, sin embargo, únicamente en los poemas de tema filosófico, cuyo estilo barroquizante contrasta con el resto del poemario.

${ }^{6}$ Cartas del fervor. Correspondencia con Maurice Abramowicz y Jacobo Sureda (1919-1928), pról. J. Marco, not. C. García, Galaxia Gutenberg-Círculo de Lectores-Emecé, Barcelona, 1999, p. 221.

${ }^{7}$ Un ensayo autobiográfico, pról. y trad. A. González, ep. M. Kodama, Galaxia Gutenberg-Círculo de Lectores-Emecé, Barcelona, 1999, p. 57.

${ }^{8}$ Fernando Sorrentino, Siete conversaciones con Jorge Luis Borges, El Ateneo, Buenos Aires, 1996, p. 69. 
El estilo barroco de "LA PER PlejIDAd FILOSÓFICA"

Borges tilda, en algún momento, su primer poemario de "metafísico". En este caso, la influencia del padre es más que evidente, quizá como un homenaje del joven poeta a las enseñanzas paternas o, bien, con el afán de desautomatizar la percepción de los lectores. Los poemas de tema abiertamente metafísico son "La Recoleta", "El Jardín Botánico", "El truco", "Final de año", "Remordimiento por cualquier defunción", "Amanecer", "Benarés", "Caminata" y "Alquimia". Son tantos y tan extensos los poemas en que la metafísica deviene el tema primordial, que en una reseña sobre González Lanuza, de 1924, Borges lo señala como un estigma de su primer libro: "estorba... en mi Fervor de Buenos Aires la duradera inquietación metafísica"9.

La mayoría de estos poemas tiene una extensión considerable: entre ellos se encuentran los más largos del poemario, como "Amanecer" y "Caminata", que constan de 55 y 48 versos, respectivamente, sólo comparables con los 52 de "Sábados" que aglutina al menos tres poemas publicados previamente, más dos estrofas sin antecedentes en revistas. Hay, entre estos poemas de cuño metafísico, también dos que no rebasan los 15 versos ("Final de año" y "Remordimiento por cualquier defunción"); los demás oscilan entre los 21 y los 43 versos.

El juicio de Adolfo Prieto, el primer crítico en dedicar un libro completo a la obra de Borges, revela cuánto ruido produjo la particular manera de asumir la filosofía como tema poético, aun en los lectores especializados. Según él, Borges sería un "pensador a mitad de camino de poeta, [que] le ha faltado el fuego interior que lo quemase en el logro total de un poema" ${ }^{\text {. }}$ A lo largo del capítulo dedicado a la poesía de Borges, que en ese momento se limitaba a los tres poemarios de los años veinte, Prieto señala los extremos en que se ubica la temprana producción borgeana: por un lado, la abundancia de imágenes

9 “E. González Lanuza. Prismas", en Inquisiciones, Proa, Buenos Aires, 1925, pp. 98-99. Esta manera de proceder, indudablemente va a contracorriente de lo que Borges defendía en "Anatomía de mi ultra": "Yo -y nótese bien que hablo de intentos y no de realizaciones colmadas- anhelo un arte que traduzca la emoción desnuda, depurada de los adicionales datos que la preceden. Un arte que rehuyese lo dérmico, lo metafísico y los últimos planos egocéntricos o mordaces" (Ultra, 1921, núm. 11).

${ }^{10}$ Borges y la nueva generación, Letras Universitarias, Buenos Aires, 1954, p. 66 . 
desarticuladas (aunque considera algunas rescatables) y, por el otro, el carácter reflexivo de algunos poemas, entre los que destacan "La Recoleta": "una difusa reflexión de reflexiones" y "Remordimiento por cualquier defunción": "El poema es una reflexión aguda comentada de imágenes" $"$.

Los ejemplos que el crítico aduce para ilustrar las limitaciones del desmañado poeta coinciden con los poemas que aquí he llamado "metafísicos". Acaso el énfasis en el proceso argumentativo que se aprecia en los recursos estilísticos y en la necesidad de mostrar una idea por medio del verso motivan esta declaración objetable, porque se enfoca sólo en algunos aspectos y deja otros de lado, que bien podrían sugerir el esfuerzo del poeta por crear un estilo que, a la larga, fraguará en la poesía borgeana de madurez ${ }^{12}$ :

Los versos de Borges ofrecen en buena parte los caracteres de la prosa, condición desfavorable que se acrece con el hábito de introducir en los poemas, giros que pertenecen por completo al dominio de la prosa, como la formulación de definiciones, el corolario de algún pensamiento, la explicación de un proceso; el discurso estrictamente lógico, en suma ${ }^{13}$.

Me parece que el análisis de Prieto atina a entrever los resortes de uno de los estilos de Fervor; pero carece de ecuanimidad: si bien tiene razón en que es más común hallar definiciones, corolarios y explicaciones en la prosa, no veo la razón para que éstos sean censurados en la poesía; más abajo traeré a colación contraejemplos en que Borges parece buscar un estilo acorde con su asunto.

Por lo demás, esta particularidad fue entrevista por los primeros comentaristas de Fervor; por ejemplo, Rafael de Diego apuntaba que no se trataba de "una obra maestra" en sentido

${ }^{11}$ Ibid., pp. 51-52. Y agrega: "Señalando la dicotomía de procedimientos seguidos por el autor, notamos que aquellos poemas que no fueron redactados según un conciso esquema mental, no son más que un rosario de presuntas metáforas y laboriosas imágenes” (p. 60).

${ }^{12}$ La filosofía, así, deviene un constituyente de la poesía, no un apéndice. Como señala JuAn Arana, Borges "busca en la filosofía más el resplandor de la intuición que el sordo fragor del raciocinio": la filosofía como fuente de la literatura ("Borges y el canon filosófico", en El laberinto de los libros: Jorge Luis Borges frente al canon literario, ed. A. de Toro, OLMS, Hildesheim, 2007, p. 95).

${ }^{13}$ Adolfo Prieto, op. cit., p. 58. 
alguno, sino de una obra poética a secas; luego agrega: "respetamos el nombre de poemas aunque debemos declarar que tal designación no les conviene en general aunque fuere con el agregado de poemas en prosa; gran parte son poesías traducidas en prosa"14.

Por su parte, Antonio Aíta sostiene también una opinión negativa sobre la poesía temprana de Borges: "La poesía de Borges parece la poesía de un licenciado de filosofía en trance de escribir versos por puro ejercicio retórico. Carece de emoción lírica toda la obra poética de este espíritu tan valioso" ${ }^{15}$. Aunque no adopta la misma actitud de Aíta, Cansinos Assens definía a Borges como "un poeta con algo de profesor y de filósofo" 16 . Estas primeras críticas, coincidentes en algún modo, estigmatizaron al joven poeta. Prieto, así, resulta el extremo más lejano de la cadena.

En general, los estudiosos de Borges han pasado por alto que Fervor contiene poemas deliberadamente barrocos, no obstante que Ramón Gómez de la Serna lo hiciera notar en su reseña de Fervor: "un Góngora más situado en las cosas que en la retórica retiembla en la copa de Borges. El mundo extraño, que trepida un poco, se refleja en ese fino cristal removido en al aparador de fino alerce"17.

El mismo Cansinos Assens apunta la tendencia barroquizante en Fervor: "[incurre] en gongorismos de una gracia arcaica y barroca. La modernidad exprésase en él por medio de un vehículo anticuado" 18 . Para comprobar esta afirmación nada más hay que leer unas líneas de "A quien leyere", el prefacio de Fervor.

Los arcaísmos léxicos y la torcida sintaxis, cuya principal característica consiste en postergar la relación entre los constituyentes de la oración, o el carácter amplificatorio de la subordinación de subordinadas, delatan la cercanía del joven Borges

14 "Fervor de Buenos Aires", Nosotros, 1923, núm. 173, p. 338. Al final, parece que De Diego se siente estafado: "Y esa es en verdad la equivocación del señor Borjes (sic) y de muchos escritores nuestros que pretenden hacernos pasar por versos algo que no debe ser considerado bajo este carácter" (p. 221).

15 "La literatura de vanguardia", Nosotros, 1930, núm. 68, p. 27.

${ }^{16}$ La nueva literatura, Páez, Madrid, 1927, t. 3, p. 287.

${ }^{17}$ ROcc, 1924, núm. 10, p. 125. Gómez de la Serna exime a Borges de un retoricismo exacerbado, pero en seguida se verá que hay un concienzudo trabajo retórico en los poemas borgeanos de corte metafísico.

${ }^{18}$ R. Cansinos Assens, op. cit., p. 290. 
con los escritores de los siglos XVI y XVII: la mención de fray Luis de León, Quevedo, Góngora y Browne en "A quien leyere" no resulta en absoluto gratuita ${ }^{19}$.

En diversas oportunidades, Borges señaló este rasgo distintivo de su primer libro; por ejemplo, en 1966 escribió:

En 1923 publiqué un libro injustamente famoso, llamado Fervor de Buenos Aires. En ese libro hay una evidente discordia entre el tema, o uno de los temas, o el fondo del libro que es la ciudad de Buenos Aires, sobre todo algunos barrios, y el lenguaje en que yo escribi, un español que quería parecerse al español latino de Quevedo y de Saavedra Fajardo. Hay una discordia evidente entre la imagen de Buenos Aires y el español latinizante de los grandes prosistas españoles de mil seiscientos y tantos, de modo que ese libro, para mí, es un libro que entraña un fracaso esencial ${ }^{20}$.

Y en la segunda edición de Fervor, en 1969:

He mitigado sus excesos barrocos... Yo, por ejemplo, me propuse demasiados fines: remedar ciertas fealdades (que me gustaban) de Miguel de Unamuno, ser un escritor español del siglo diecisiete, ser Macedonio Fernández, descubrir las metáforas que Lugones ya había descubierto, cantar un Buenos Aires de casas bajas y, hacia el poniente o hacia el sur, de quintas con verjas ${ }^{21}$.

A mi juicio, el barroquismo de Fervor resulta más explícito en los poemas de tono metafísico ${ }^{22}$. En un primer momento,

${ }^{19}$ Fervor de Buenos Aires, Serantes, Buenos Aires, 1923, s.p. La mención explícita de estos autores barrocos por excelencia, así como la de Jorge Manrique y fray Luis de Granada en "La Recoleta", de alguna manera, obliga a establecer un nexo estilístico o temático entre el incipiente poeta y sus precursores, en el sentido borgeano.

20 "Poetas de Buenos Aires", Testigo, 1966, núm. 1, en Textos recobrados III (1956-1986), eds. S.L. del Carril y M. Rubio de Zocchi, Emecé, Buenos Aires, 2003 , p. 125.

${ }^{21}$ Fervor de Buenos Aires, $2^{\mathrm{a}}$ ed., Buenos Aires, Emecé, 1969, p. 9.

${ }^{22}$ Concuerdo, por ello, con Laura Milano y Rosa María Ravera, quienes en un abigarrado ensayo sobre "El barroquismo borgeano" comentan: Borges funda buena parte de su narrativa en un estilo barroco que sólo define "en superficie pero lo utiliza en profundidad". Se trata, según las estudiosas, de un barroquismo no sólo de formas, sino esencial que coincide con, por ejemplo, la semiosis ilimitada de Peirce y otras modernas corrientes de pensamiento (cf. Fernando de Toro y Alfonso de Toro, Jorge Luis Borges. Pensamiento y saber en el siglo XX, Vervuert, Frankfurt, 1999, pp. 321-345). 
analizaré los íncipit de los poemas metafísicos para desarticular un estilo que, antes que ocultar, revela la preocupación por las "tecniquerías" que tanto fustigó Borges en los poetas modernistas. Después, haré una lectura minuciosa de "La Recoleta" y "Amanecer", con el ánimo de mostrar los resortes de la poesía de tema metafísico. En los versos iniciales de "La Recoleta" se lee:

Convencidos de caducidad

vueltos un poco irreales por el morir altivado en tanto sepulcro irrealizados por tanta grave certidumbre de muerte, nos demoramos en las veredas

(vv. 1-4).

Las construcciones nominales de los tres primeros versos, que además cumplen una función anafórica, mantienen en suspenso al sujeto gramatical que modifican: éste sólo se deduce del verbo principal, "nosotros". Además, el sentido intensificador de estos versos pasa por tres momentos: primero hay un convencimiento de la caducidad, luego un desvanecimiento del sujeto ("vueltos un poco irreales" ante "el morir altivado") y, finalmente, una transformación: ocurre un despojo definitivo del yo lírico, "irrealizados", frente a la "certidumbre de muerte".

Estos primeros versos de "La Recoleta" pueden considerarse como un ejemplo de correlación o, como lo denomina Dámaso Alonso, "de pluralidad"23. La estructura paralelística adjetivo + modificador con preposición hace énfasis no sólo en la relación horizontal entre los versos comentados, sino también en la vertical, es decir, se trata de un tipo especial de pluralidad, de "hibridismo progresivo-reiterativo". Además de que se nota una progresión gradual en esta reflexión sobre la muerte, también es perceptible un solo patrón en la estructura gramatical.

La acumulación de elementos que impide la aparición inmediata del sujeto también puede observarse en el íncipit de otros poemas como "El Jardín Botánico":

${ }^{23}$ El teórico español señala que "lo plural, en el despliegue de sus miembros, es una de las inclinaciones constantes de la expresión literaria de todos los pueblos y todas las épocas", por ello propone el estudio de "pluralidades cuyos miembros sean (o puedan ser considerados) «semejantes» entre sî" ("Introducción", en D. Alonso y Carlos Bousoño, Seis calas en la expresión literaria española, $4^{\mathrm{a}}$ ed., Gredos, Madrid, 1979, pp. 14-15). 
Muy lejos de nosotros

por más que nuestras manos atestigüen los troncos

los árboles que balbucean apenas el ser

sueltan en pos de lo desconocido

5 su vana lumbrerada de hojas ciegas

que en piadosa ficción arriba se abrazan

como dobladas por la combadura celeste.

Mediante el hipérbaton, el sujeto gramatical es desplazado hasta el tercer verso; mientras que la subordinada adjetiva que modifica al sujeto envía el verbo principal hasta el cuarto verso. También en los primeros versos de "Remordimiento por cualquier defunción" se aprecia una aglutinación inicial que posterga al sujeto:

Inconmensurable, abstracto, casi divino, desbaratadas las trabaduras del ser, el muerto ya no es un muerto: es la muerte (vv. 1-3).

En "Amanecer”, también un giro sintáctico desplaza al sujeto hasta el tercer verso y el verbo al cuarto:

En la honda noche universal que apenas contradicen los macilentos faroles una racha perdida ha ofendido las calles taciturnas

(vv. 1-4).

El sujeto lírico prepara el escenario de su experiencia poético-filosófica y, de esa manera, influye en la recepción del poema: primero para atraer la atención del lector y luego, ya con la lectura en marcha, desarrollar sus argumentos acerca de la muerte, el tiempo o la inconsistencia de la realidad.

Como puede apreciarse en los primeros versos de los poemas metafísicos, no sólo se intenta crear una expectativa en el lector, sino enfrentarlo con una concepción nueva: el sujeto lírico asume los temas del tiempo o la muerte mediante un lenguaje poético que raya en la naturalidad: apariencia que denota un gran esfuerzo de artificialidad retórica ${ }^{24}$.

${ }^{24}$ Hay que reconocer que "muchas veces sucede que lo que parece más natural, más espontáneo, es lo más artificioso" (Alonso, "Introducción”, p. 18). 
El evidente barroquismo de estos poemas, además de basarse en el retorcimiento sintáctico que he esbozado, funciona por acumulación, principalmente, como se deduce del uso reiterativo de las anáforas, de las subordinadas y de los múltiples modificadores del sujeto: estos recursos estilísticos tienen como principal objetivo preparar la recepción del poema, al tiempo que revelan el tema.

\section{EL POETA Y LA MUERTE}

"La Recoleta" remite de manera inmediata al panteón más famoso de Buenos Aires y, por lo tanto, a la muerte. Este poema, por ello, resulta paradigmático: en él se crea una tensión entre vida y muerte que el sujeto lírico intenta resolver mediante la argumentación que, al final, lo lleva a pensar en su propia condición de mortal.

Por los testimonios epistolares hoy se sabe que el joven Borges fue un lector fervoroso de literatura española de todos los tiempos; en sus cartas a Abramowicz y Sureda aparecen referidos los romances medievales, san Juan de la Cruz, Cervantes, Quevedo, Góngora, Baroja, Unamuno, Xènius y Pérez de Ayala, entre otros ${ }^{25}$. Es más: varios textos incluidos en sus tres primeros libros de ensayos están dedicados a Cervantes, Góngora, Quevedo, Torres Villarroel, Unamuno, Cansinos Assens y Jorge Manrique, así como un agudo análisis del culteranismo.

Destaca entre dichos ensayos "Las Coplas de Jorge Manrique", por dos cosas: por una parte, porque Manrique es mencionado en el v. 9 de "La Recoleta", lo que sugiere una línea de lectura del poema y, por otra, porque Borges aprovecha este ejercicio de análisis literario para filosofar sobre diferentes formas de concebir la muerte. El ensayo inicia con una afirmación contundente: "La más escuchada voz que verso habló de la muerte, es la de Manrique"26. Asimismo, Borges halla en las Coplas una entonación que coincide con la de "La Recoleta"; es decir, ni en aquéllas ni en ésta aflora el patetismo que la muerte provoca, ni dramatismo ni sorpresa: al igual que en el poema

${ }^{25}$ Cartas del fervor, passim. Lecturas estas que el joven Borges combinaba con las de los expresionistas alemanes, Whitman, Nietszche, Schopenhauer, Kant y, en menor medida, de autores franceses.

${ }^{26}$ El idioma de los argentinos, M. Gleizer, Buenos Aires, 1928, p. 93. 
borgeano, se expresa "la forzosidad del morir, pero nunca lo disparatado de ese acto ni el azoramiento metafísico a que nos invita ni un esperanzarse curioso en la inmortalidad". Difiere, sin embargo, en una cosa: mientras para Manrique y cualquier español la "perdurabilidad es la única forma del ser", para Borges "el esqueleto sobrevive a su portador, luego el esqueleto es más real que el hombre" 27 .

En seguida reproduzco los versos iniciales de "La Recoleta", con el ánimo de ofrecer una lectura pormenorizada de este que resulta un poema ejemplar, más que por su calidad estética, por el estilo barroco mediante el cual Borges llega a la metafísica:

Convencidos de caducidad

vueltos un poco irreales por el morir altivado en tanto sepulcro irrealizados por tanta grave certidumbre de muerte, nos demoramos en las veredas que apartan los panteones enfilados cuya vanilocuencia hecha de mármol, de rectitud y sombra interior equivale a sentencias axiomáticas y severas de Manrique o de Fray Luis de Granada (vv. 1-9).

Las coincidencias que presentan los íncipit de los poemas metafísicos de Fervor, tanto en su forma cuanto en su función, también pueden apreciarse en su desarrollo o, en otras palabras, en el proceso de la reflexión poética. En "La Recoleta", por ejemplo en los vv. 4-9, se notan los rasgos estilísticos que Borges imprimió en los tres primeros versos del poema y, más todavía, parece obstinado en literaturizar sobre la muerte: las "veredas" son modificadas por la subordinada "que..." y "panteones", a su vez, por "cuya..." y, por último, "vanilocuencia" por "[que está] hecha...", con lo cual el lector entra en una especie de mise en abîme a tono con el tema del poema: la complejidad de la reflexión metafísica tiene su correspondencia en la complejidad formal.

Asimismo, el v. 7 se trifurca: "de mármol, de rectitud y sombra interior"; mientras los vv. 8 y 9 presentan sendas bimembraciones: "axiomáticas y severas", "de Manrique o de Fray Luis de

${ }^{27}$ Y para seguir con la paradoja de la muerte, agrega Borges: "Yo no entiendo de estas divisiones jerárquicas de la realidad y no sé por qué razón la hora de la muerte ha de ser más verdadera que las de vivir y el viernes y el lunes. Si todo es ilusorio, también la muerte lo es y muere su muerte" (ibid., pp. 96-98). 
Granada”. Arcaísmo deliberado, este par de bimembraciones emparienta formalmente el poema de Borges con la escritura barroca, al mismo tiempo que la mención explícita de dos poetas españoles lo sitúa dentro de una tradición lírica y dentro de un campo temático. Al aludir a Jorge Manrique y fray Luis de Granada, Borges establece un nexo explícito con la herencia literaria hispánica: las Coplas a la muerte de su padre y la Guía de pecadores (principalmente el capítulo 2) son libros de sentencias, pues su principal objetivo consiste en hacer consciente al hombre, primero, de su perennidad y, luego, de la necesidad de vivir ejemplarmente para morir en la gracia de Dios y, después de muerto, ser digno de emulación.

Luego viene lo que podría llamarse propiamente el encuentro del sujeto lírico con la viva realidad de los muertos y la revelación de su propia condición de mortal:

10 Hermosa es la serena decisión de las tumbas, su arquitectura sin rodeos y las plazuelas donde hay frescura de patio y el aislamiento y la individuación eternales; cada cual fue contemplador de su muerte

15 única y personal como un recuerdo.

Nos place la quietud, equivocamos tal paz de vida con el morir y mientras creemos anhelar el no-ser lanzamos jaculatorias a la vida apacible.

20 Vehemente en las batallas y remansado en las losas sólo el vivir existe.

Son aledaños suyos tiempo y espacio, son arrabales de alma son las herramientas y son las manos del alma

25 y en desbaratándose ésta, juntamente caducan el espacio, el tiempo, el morir, como al cesar la luz se acalla el simulacro de los espejos que ya la tarde fue entristeciendo.

Es notable un esquema retórico que abunda en el uso de pluralidades, como en los vv. 10-12 en que un predicativo ("Hermosa") modifica triplemente, mediante el hipérbaton, a "la serena decisión", "su arquitectura" y "las plazuelas", que a la postre funcionan como un sujeto compuesto cuyo tercer miembro también se trifurca con la subordinada adjetiva "donde hay": 
"frescura de patio (1) / y el aislamiento (2) y la frescura eternales" (3); por si fuera poco, el polisíndeton confirma esta especie de árbol lingüístico en constante crecimiento. Y para subrayar el barroquismo, otra bimembración se halla en los vv. 14-15: "muerte / única y personal".

Este proceso acumulativo o expansivo, así como el tono pensativo del sujeto lírico, hacen ver el tema de la muerte como algo neutro, descargado de toda connotación negativa: Borges, se diría, va más allá del dramatismo y se inscribe entre la argumentación racional y la efusión sentimental; es más, halla cierto encanto en la contemplación de la muerte, como se lee en los vv. 15-35, donde el yo lírico razona la vida y la muerte al tiempo que disfruta la placidez del cementerio; "Nos place la quietud", dice, y en ese estado de gozo, vida y muerte se confunden: "equivocamos tal paz de vida con el morir". El escenario lo invita a pensar en su propia muerte, entonces:

Sombra sonora de los árboles, viento rico en pájaros que sobre las ramas ondea, alma mía que se desparrama por corazones y calles, fuera milagro que alguna vez dejaran de ser, milagro incomprensible, inaudito aunque su presunta repetición abarque con grave horror la exis-

La presunta repetición que abarca "con grave horror la existencia" resulta ambigua, porque bien puede referirse a la pluralidad de los vv. 30-32: "sombra sonora", "viento rico" y "alma mía"; pero también a "milagro incomprensible"; el posesivo "su", por ello, también multiplica los significados. Además, resulta pertinente anotar cómo en estos seis versos todos los sustantivos se hallan modificados, ya por un adjetivo a secas (como en las cuatro estructuras nominales citadas arriba), ya por una subordinada adjetiva (como "que sobre las ramas ondea" o "que se desparrama por corazones y calles"), hecho que Borges no vio con buenos ojos en la poesía gongorina ni en la poesía modernista encabezada por Darío ${ }^{28}$. Este abuso de la

${ }^{28}$ Siempre atento al artefacto retórico que es el poema, BoRGEs expresó en varias ocasiones su opinión al respecto, como en la reseña que escribió sobre Andamios interiores, en 1922, donde acusa a Darío de explotar una adjetivación puramente ornamental mientras exalta la innovadora adjetivación de Maples Arce: “Generoso en imágenes preclaras, el estilo de Maples Arce 
adjetivación en varios poemas de Fervor representa la intención expresa de ramificar el pensamiento mediante la ramificación de la sintaxis.

Sobre el desarrollo expositivo del poema, vv. 10-35, debe decirse que despliega recursos heterogéneos que revelan una tensión constante entre forma y contenido: esto es, los vv. 15-19, cuya deuda con el discurso en prosa es evidente; mientras en los vv. 20-35 el trabajo retórico salta a la vista en las estructuras bimembres y trimembres, y hasta paralelísticas, así como en la recurrencia a la adjetivación de manera incisiva. En el primer caso, la reflexión fluye sin trabas, por lo que el lector fija únicamente su atención en qué se dice; pero en el segundo se ve obligado a concentrarse en qué y cómo se dice.

El final de "La Recoleta" también parece estar sometido a la tensión general del resto del poema entre la materia poética y su expresión; asimismo, resulta significativa la manera en que el sujeto lírico concluye: no solamente pasa del plural mayestático a la primera persona, sino que hace explícito el carácter meditativo del poema:

Lo anterior: escuchado, leído, meditado

lo realicé en la Recoleta,

junto al propio lugar donde han de enterrarme (vv. 36-38).

La reflexión sobre la muerte, sin énfasis ni aspavientos, lleva al yo lírico a sopesar su propia condición pasajera, no con resignación sino consciente de que es apenas un eslabón en la cadena de esa "presunta repetición" que es el género humano. Esta situación placentera también tiene que ver con el lugar de la meditación sobre la muerte; cuando el sujeto lírico entrevé su entierro en La Recoleta ("junto al propio lugar donde han de enterrarme"), el cementerio de la aristocracia argentina, asume un sentido de pertenencia, porque la muerte, así, reafirma la pertenencia a una clase social determinada. La serenidad de la meditación proviene del doble bienestar, presente y futuro.

lo es también de adjetivos, cosa que no debemos confundir con el charro despliegue de epítetos gesteros que usan los de la tribu de Rubén. Ya que es a todas luces evidente que una adjetivación laudable no ha de atenerse al prestigio de los vocablos aislados sino a la conjunción feliz de ambas voces" (Inquisiciones, p. 122). 
Para el joven Borges, además, la muerte individual no afecta la vida colectiva: cada hombre es una suerte de medio, en constante renovación, que la especie requiere para perpetuarse, por ello el sujeto lírico de "Final de año" se azora de que a pesar del tiempo, y "sus metafísicas posibilidades", "pueda persistir algo en nosotros / inmóvil” (vv. 14-15).

En última instancia, entre vivos y muertos hay un doble hilo conector: aquéllos disfrutarán del mundo material, las ideas y el tiempo como un tesoro mal habido que los muertos heredaron, a su vez, de otros muertos:

Todo se lo robamos, no le dejamos ni una brizna de cielo:

10 aquí está el patio que ya no palpan sus ojos, allí la acera donde acechó la esperanza.

Aún [sic] lo que pensamos podría estarlo pensando él también; nos hemos repartido como ladrones

15 el asombroso caudal de noches y días ("Remordimiento por cualquier defunción").

\section{EL SER Y LA NADA SEGÚN GEORGIE}

Entre el cúmulo de escritos borgeanos de los años veinte sobresalen los ensayos dedicados a la defensa del idealismo y, por lo tanto, a la discusión sobre el ser de las cosas: "La nadería de la personalidad" (Proa, $1^{a}$ ép., agosto de 1922, núm. 1) y "La encrucijada de Berkeley" (Nosotros, enero de 1923, núm. 164), que después pasaron a formar parte de Inquisiciones ${ }^{29}$; puede añadirse a la lista "El cielo azul, es cielo y es azul" (Cosmópolis, agosto de 1922, núm. 44). El primer ensayo citado se abate contra la porosidad del "yo", contra la existencia de un "yo de conjunto"; el segundo se dedica a exponer los argumentos de Berkeley acerca del ser: "Esse rerum est percipi: la perceptibilidad es el ser de las cosas: sólo existen las cosas en cuanto son percibidas", traduce Borges el principio berkeleyano ${ }^{30}$. Por último, "El cielo

${ }^{29}$ Son éstos los únicos ensayos del volumen que tratan abiertamente temas filosóficos (véanse pp. 84-95 y 109-119).

${ }^{30}$ Ibid., p. 110. Más adelante, Borges aceptará la tesis de Berkeley, pero matizada: "Berkeley afirma: Sólo existen las cosas en cuanto se fija en ellas 
azul..." consiste en una defensa del idealismo de Schopenhauer, a partir de los conceptos de voluntady representación que rigen el sistema de este filósofo alemán ${ }^{31}$.

Pero la "inquietación metafísica" no se quedó en la labor ensayística, sino que se extendió a otros géneros como la epístola y la poesía; un ejemplo del primer caso es la carta que Borges escribió a su amigo Jacobo Sureda, desde Buenos Aires, en junio de 1921:

Yo, de ti me arrojaría de cabeza en el estudio de la metafísica. Encuentro que el Libre Albedrío, el Determinismo, el problema de si existe o no el Yo, el estudio de lo que son Tiempo y Espacio, el problema del conocimiento, etc... son mucho más interesantes que lo de oírle a un poeta relatar que la luna parecía una claraboya o que su novia tiene trenzas rubias. ¿Y qué es la literatura, en general, sino un barajar de asociaciones o nimiedades como ésas? ${ }^{32}$

la mente. Lícito es responderle: Sí, pero sólo existe la mente como perceptiva y meditadora de cosas. De esta manera queda desbaratada, no sólo la unidad del mundo externo, sino la espiritual" (p. 115).

${ }^{31}$ La postura mediadora de Schopenhauer, que sostiene "la imposibilidad de un sujeto sin objeto y viceversa", impresionó al joven BorGES, quien con estilo didáctico expone la filosofía de aquél: "el paisaje no puede existir sin alguien que se perciba de él, ni yo sin que algo ocupe el campo de mi conciencia. El mundo es, pues, representación, y no hay ligadura causal entre la objetividad y el sujeto. Pero además es voluntad, ya que cada uno de nosotros siente que a la briosa pleamar y envión continuo de las cosas externas podemos oponer nuestra volición. Nuestro cuerpo es una máquina para registrar percepciones; mas es también una herramienta que las transforma como quiere. Esta fuerza cuya existencia atestiguamos todos es la que llama voluntad Schopenhauer: fuerza que duerme en la rocas, despierta en las plantas y es consciente en el hombre..." (Textos recobrados [1919-1929], eds. S.L. del Carril y M. Rubio de Zocchi, Emecé, Buenos Aires, 1997, pp. 155-156).

${ }^{32}$ En seguida, Borges contradice a Sureda con los argumentos de la filosofía idealista: "Me gustaría discutir intensamente contigo lo que me dices sobre la Materia. Tú escribes: «Hemos convenido en llamar materia al conjunto de circunstancias sensoriales». Y después: «Sensación es la percepción de la materia». Con lo segundo no estoy de acuerdo. Existen una cantidad de sensaciones desparramadas: colores, ruidos, gustos, olores, sensaciones de peso y de extensión y resistencia... la materia la constituyen una serie de síntesis de percepciones que aunque tiene valor de símbolos o de puntos de referencia en la vida corriente, carecen en sí de realidad" (Cartas del fervor, pp. 201-202). 
Como se observa, esta cita anticipa la afirmación borgeana de que la filosofía es un género de la literatura fantástica ${ }^{33}$. A esta invitación, Sureda objetó la imposibilidad de hablar sobre puntos tan cruciales para el joven Borges, quien lanza una nueva embestida en carta de $c a$. del 30 de agosto de 1921:

Tienes sobrada razón al constatar la imposibilidad de discutir conmigo Metafísica a tan larga distancia. Únicamente te haré notar una cosa: es tan difícil suponer un dolor que nadie siente, como un color que nadie ve o una dureza que nadie palpa. Es decir, no hay objetividad y la idea materialista de causas y efectos no tiene ni pies ni cabeza ${ }^{34}$.

Casado con la idea de que la metafísica puede considerarse una fuente literaria, Borges en Fervor parte de una experiencia individual para defender su posición filosófica respecto del ser de las cosas: "Amanecer" representa el testimonio de una noche en que el sujeto lírico no solamente asiste a la resurrección del día, sino que se siente cómplice de ello, pues al mismo tiempo que permanece vigilante, mientras otros duermen, su percepción salva de la nada al mundo.

Los primeros versos de "Amanecer" constituyen el escenario de la experiencia metafísica: "la honda noche universal" amenaza la existencia del mundo circundante; pero, héroe anónimo, el yo poético halla un momento inmejorable para demostrar, "curioso de la descansada tiniebla / y acobardado por la amenaza del alba" (vv. 9-10), que Schopenhauer y Berkeley superan inevitablemente a los filósofos materialistas. Un poco a

33 "Si nos avenimos a considerar la filosofía como un ramo de la literatura fantástica (el más vasto, ya que su materia es el universo; el más dramático ya que nosotros mismos somos el tema de sus revelaciones), fuerza es reconocer que ni Wells ni Kafka, ni los egipcios de las 1001 NOCHESjamás urdieron una idea más asombrosa que la de este tratado", se lee en una nota de factura borgeana que antecede la traducción de un fragmento de Parerga und paralipomena, de Arthur Schopenhauer ("Fantasía metafísica", Anales de Buenos Aires, 1946, núm. 1, p. 54).

${ }^{34}$ Cartas del fervor, p. 204. Por lo que se ve, el esfuerzo de convencer a Sureda de la superioridad del idealismo sobre el materialismo hizo mella, ya que un año después Borges escribe al mallorquín (en septiembre de 1922): “¿Qué me dices de Proa y de esa pelma sobre «La Nadería...» que es otra carta enderezada a tu conversión al idealismo marca [Schopenhauer]? Te mando además la añadidura de otra escaramuza mía semi-filosófica que se publicó en Cosmópolis" (p. 225). La "otra escaramuza" a favor del idealismo debió ser "El cielo azul, es cielo y es azul". 
la inversa de "La Recoleta", cuyo final sintetiza y revela el carácter meditativo del poema, en "Amanecer" se anuncia desde los primeros versos la intención raciocinante del sujeto lírico, así como el asunto del poema y sus fuentes autorizadas:

Curioso de la descansada tiniebla

10 y acobardado por la amenaza del alba

realicé la tremenda conjetura

de Schopenhauer y de Berkeley

que arbitra ser la vida

un ejercicio pertinaz de la mente,

15 un populoso ensueño colectivo

sin basamento ni finalidad ni volumen.

Y ya que las ideas

no son eternas como el mármol

sino inmortales como una selva o un río,

20 la precitada especulación metafísica

al atalayar desde mi cráneo el vivir

tuvo una forma inusitada

y la superstición de esa hora

cuando la luz como una enredadera

25 va a implicar las paredes de la sombra,

doblegó mi pensar

y trazó el capricho siguiente:

Como puede notarse, en esta primera parte del poema se impone el ejercicio reflexivo sobre el aparato retórico, si bien es notable una intención lírica mediante la comparación en dos versos consecutivos: "no son eternas como el mármol / sino inmortales como una selva o un río" y, más adelante: "cuando la luz como una enredadera"; asimismo, el uso de infinitivos sustantivados como "el vivir" y "mi pensar", en lugar de "la vida" y "mi pensamiento", de alguna manera desautomatizan la percepción del lector; pero también delatan el afán retoricista del joven Borges ${ }^{35}$.

${ }^{35}$ Borges achaca la sustantivación de infinitivos a la influencia de Macedonio Fernández, al tiempo que revela un afán retoricista en la hechura de este poema: "Él me dejó ciertas malas costumbres literarias; por ejemplo, en lugar de decir la vida, que es mucho más simple, ¿no?, en mis primeros textos yo decía el vivir, le viure. Esa pedantería pertenece a la manera oral e incluso escrita de Macedonio Fernández. Él afirmaba que era más expresivo decir el vivir que la vida, que en vez de decir el amor, por ejemplo, debía decirse el amar" (JeAn De Milleret, Entrevistas con Jorge Luis Borges, trad. G. Rodríguez, Monte Ávila, Caracas, 1971, p. 32). 
Ahora bien, en la perspectiva idealista de Schopenhauer y Berkeley la vida consiste en "un ejercicio pertinaz de la mente, / un populoso ensueño colectivo / sin basamento ni finalidad ni volumen", que se impone, más que como un corolario filosófico, como un reto para el sujeto lírico que se ve obligado a comprobar tan "tremenda conjetura". Con el ambiente propicio para la reflexión, aquél vuelve "la precitada especulación metafísica" en un "capricho" de su mente: el desvanecimiento de esta "numerosa urbe de Buenos Aires" entre las sombras coincide con una progresiva pérdida de las capacidades perceptivas del yo lírico. Curiosamente, la exposición del "capricho" trazado por éste inicia a la mitad del poema, en el v. 28, como si el sujeto poético quisiera delimitar la materia del pensamiento (las ideas) y la materia física percibida (el arrabal entre las sombras de la noche).

En la segunda parte del poema (vv. 28-55) se aprecia un mimetismo deliberado: el poeta halla un momento y un espectáculo inmejorables acordes con la filosofía idealista; a la vez se observa como actor de la "resurrección cotidiana":

Si están ajenas de sustancia las cosas y si esta numerosa urbe de Buenos Aires

30 asemejable en complicación a un ejército no es más que un sueño que logran en común alquimia las ánimas, hay un instante en que peligra desaforadamente su ser ...

Pero otra vez el mundo se ha salvado.

La luz discurre inventando sucios colores y con algún remordimiento

50 de mi complicidad en la resurrección cotidiana solicito mi casa atónita y glacial en la luz turbia mientras un zorzal impide el silencio y la noche abolida

55 se ha quedado en los ojos de los ciegos.

Si como expresa Borges "el barroquismo es intelectual" los versos anteriores serían el mejor ejemplo de su aseveración;

${ }^{36}$ Véase el "Prólogo a la edición de 1954", en Historia universal de la infamia, 6 ed., Alianza-Emecé, Madrid, 1983, p. 9. 
además, resulta preciso notar dos cosas que lo particularizan: su familiaridad con el discurso en prosa, por una parte, y el afán explícito de mostrar, de construir una demostración, por otra.

El sujeto lírico, alter ego de Borges, aparece como protagonista, una de las "pocas almas que piensan"; también se asume como corresponsable de la salvación del mundo ante la impavidez de Dios, por ello exalta su "complicidad en la resurrección cotidiana”: al salvar el mundo, se salva a sí mismo. Por cierto, en una carta dirigida a Sureda, de principios de septiembre de 1922, Borges se refiere a una situación semejante a la de "Amanecer":

Hay que pensar en cosas fundamentales. Anoche, arrumbado en un cafetín de arrabal, mientras un piano, un violín y otras herramientas de aturdir apaleábanme las orejas con el quejoso tango Milonguita se me ocurrió que la cesación total de la vida sería, quizá, más asombrosa, más inexplicable y desatinada que la idea de la inmortalidad. ¿Cómo puede acabarse el vivir, tan enrevesado, tan lleno de cuanto Dios creó? ${ }^{37}$

Esta cita coincide no sólo con el tema, sino con el tono de "Amanecer"; y aunque resulte un poco aventurado, el texto de la carta bien podría considerarse una fuente del poema: los dos tienen un marco común, la noche; ambos, también, se enfrascan en una discusión metafísica en la que Dios parece un espectador más de lo que sus criaturas hacen con el mundo.

Otros poemas, como "El truco" y "Benarés", giran en torno de la inconsistencia de la realidad: en el primero, por ejemplo, los jugadores devienen una copia borrosa de otros jugadores de truco que los antecedieron: al salir del flujo natural del tiempo, de "la maciza realidad primordial" (v. 4), los jugadores recuperan el momento fundacional del truco y se trasladan a la época de Rosas y los gauchos; mientras en el segundo, la imaginación del sujeto lírico recrea una ciudad desconocida, "que mis pisadas no conocen" (v. 4); luego, se decepciona por la certeza de que la ciudad imaginada apenas si tiene que ver con la Benarés real, hermana gemela de Buenos Aires ${ }^{38}$. En los dos casos, la realidad es puesta a prueba: en "El truco" los jugadores, a pesar de su situación en un tiempo y espacio determinados, parecen estar

${ }^{37}$ Cartas del fervor, p. 225.

${ }^{38}$ Más aún: el sujeto poético se percata de que mientras "[brujulea] las imágenes" la ciudad que canta mantiene su "injuriosa miseria", sus arrabales y cuarteles con sus hombres miserables (vv. 40-43). 
repitiendo el primer juego de truco: "a pesar de las apariencias, nada cambia", dice Iván Almeida ${ }^{39}$. En "Benarés", el sujeto lírico experimenta la ilusión de un lugar que, a la vez, se refleja en otro. Al final, este ejercicio, en apariencia inocente, permite al sujeto lírico poner en tela de juicio la estabilidad del ser.

Después de este ejercicio de análisis, puede afirmarse que el cruce entre filosofía y poesía constituye un pilar híbrido en la obra borgeana desde los años veinte. Más que un defecto, como lo vieron sus primeros críticos, el uso de la filosofía en Borges representa un elemento estructural, como el género policiaco o la autobiografía en sus relatos. Al mismo tiempo, confirma la diversidad estilística y temática de Fervor de Buenos Aires: Borges estaba más cerca de los escritores que censuraba, verbigracia Darío y Góngora, como se desprende de la identificación de los artilugios retóricos de los poemas filosóficos. Una lectura más global del primer poemario de Borges arrojaría luces sobre cómo integra temas como la estirpe familiar, los atardeceres, la ciudad y sus calles, el amor... a la vez que practica desde el estilo barroco hasta la búsqueda de un estilo llano como en "Llaneza" o "Inscripción sepulcral" ("Para el coronel don Isidoro..." y "Para el coronel don Francisco...").

Antonio Cajero

El Colegio de San Luis Potosí

39 “De Borges a Schopenhauer”, VBorges, 2004, núm. 17, p. 128. Esta “idea de una inexorable permanencia del ser que trasciende las individualidades personales" también afecta a los animales y los objetos, como el ruiseñor de Keats y el puñal que es todas las armas de la historia (pp. 129-130). 